\title{
Assessment of Instructors' Technology Competency to be Used in the Settings of Formal and Non-Formal Education
}

\author{
Myroslava P. Vovk ${ }^{1}$, Halyna I. Sotska ${ }^{1}$, Olena V. Trynus ${ }^{1} \&$ Olga Ja. Muzyka ${ }^{2}$ \\ ${ }^{1}$ Ivan Zyazun Institute of Pedagogical Education and Adult Education, Ukraine National Academy of Sciences, Kyiv, \\ Ukraine \\ ${ }^{2}$ Uman State Pedagogical University named after Pavlo Tychyna, Uman, Ukraine \\ Correspondence: Halyna I. Sotska, Ivan Zyazun Institute of Pedagogical Education and Adult Education, Ukraine \\ National Academy of Sciences, 9, Berlynskogo str., Kyiv, 04060, Ukraine. E-mail: phdphd509@ gmail.com
}

Received: July 18, 2019

Accepted: August 1, 2019

Online Published: August 2, 2019

doi:10.5430/ijhe.v8n5p29

URL: https://doi.org/10.5430/ijhe.v8n5p29

\begin{abstract}
The purpose of this study was to test the model of diagnostic assessment of the level of formedness of the competency of pedagogical staff to use teaching technologies when applied in the settings of formal and non-formal education and to see whether the model creates opportunities for designing a strategy for professional lifelong development of teaching staff. A convergent (computer-oriented and traditional) methodology was used in this study including: the methodology for examination of the motivation drivers of professional activity (K. Zamfir); "Square of Values" methodology by O. Murzina; methodology of self-assessment of vocational and pedagogical motivation, Bass's questionnaire on orientations entitled "Personality orientations", Henning's methodology called "Structure of Interests", Criteria Cognitive Aptitude Test. It has been proved that the majority of teaching staff demonstrated the imitative and reproductive level of formedness of the professional competency consistent with all criteria. It seems that educators strive for self-improvement and self-development in using teaching technology in formal and non-formal education settings. This study results can be well used either to develop the structure and content of the professional development or post-graduation programs for the teaching personnel at the instructional institutions or to assess of the level of formedness of the professional competence of pedagogical staff to use teaching technologies in the settings of formal and non-formal education. The study attempts for the first time ever to assess professionalism-related competency in using teaching technology in formal and non-formal education settings and to specify the value orientations, motives, needs, spectrum of knowledge, skills, and abilities comprising the level of proficiency in this area as it is viewed through the needs of the labour market.
\end{abstract}

Keywords: professional competence, pedagogical personnel, educational technologies, formal education, non-formal education, diagnostic assessment, diagnostic tools

\section{Introduction}

The professional competence of a teacher, if considered in the present-day optics, is associated with the use of educational technologies (Aljaberi, 2015; Gu et al., 2012; Kashyna, 2016), specifically (according to the classification referred to by Anishchenko (2011)): first, structural and logical, computer-based, training technologies aimed at practising certain educational and cognitive actions and ways of solving typical problems in the process of learning; second, distance learning technologies to train teaching staff to use learning technologies tailored to the specifics of formal and non-formal education.

The estimates of student youth to the quality of the organization of the educational process are becoming higher (Cheng, 2016; Masino \& Niño-Zarazúa, 2016). The instructional process is supposed to do both motivate (Vero \& Puka, 2017) and involve students in creative, educational, cognitive, and scientific activities (Bidabadi et al., 2016; Serdyukov, 2017) and be integrated, in which multimedia resources are used (Takeuchi et al., 2016). The examples of such technologically advanced learning models are Smart Classroom, Flipped Classroom, Sustainable one (Essays, UK, 2018; Gerstein, 2012; Omidina, Masrom \& Selamat, 2013). The above-mentioned envisages the necessity of adapting the education system based on the flexibility of all its parameters (place, time, terms of training, curricular, content, forms, methods, etc.), mobility, and the use of educational technologies (European Commission, 2018).

In educational and scientific environments employed worldwide as well as in Europe and Ukraine, the three types of 
education trends of institutionalization and technologization are recognized (Exam Planning, 2019; Lukyanova, 2011; Maksimović \& Dimić, 2016): formal (associated with the construction of a system of continuous education as part of social practices (social and educational aspects of lifelong learning)), non-formal (driven by the process of human learning of new life, social, professional experience outside of organized educational institutions), informal (involves performing self-education, self-improvement, self-development of the individual, taking into account their own preferences, aspirations, goals).

Given that the adult education in the system of formal or non-formal education should take into account the andragogical components of work with adults (Bošković, 2016; Henschke, 2014; Kononets, 2017; Werakula, Pathumcharoenwattanaa \& Amatayakula, 2014)-requirements to the activity, principles, forms and methods of adult education organization, conditions of effective application of them, individual characteristics, strategies of interaction of participants in the educational process, the need for intensification of both self-learning and collaborative activities, reliance on life and professional experience, educational needs-the instructional staff are supposed to be prepared to organize the training of various categories of adults, the use of innovative technologies in formal and non-formal education, which, in turn, actualises the need for constant professional growth, self-improvement, and continuous pedagogical reflection (McCauley, Hammer \& Hinojosa, 2017; Palis \& Quiros, 2014).

While reviewing the literature on the professionally important qualities of a teacher, the competency in using technology was found a top one. However, the empirical studies do not provide the data on a diagnostic assessment of the level of proficiency of the above quality.

In our opinion, the implementation of the pedagogical diagnostics of the level of proficiency in this area will make it possible to specify the value orientations, motives, needs, spectrum of knowledge, skills, and abilities. It will create opportunities for designing a strategy for professional development, self-education, self-improvement of teaching staff throughout their occupational life, in particular, in the settings of postgraduate education, non-formal and non-formal learning.

The purpose of our study is to empirically test the model of the diagnostic assessment of the level of formedness of the professional competence of the teaching staff regarding the use of teaching technologies, taking into account the specifics of formal and non-formal education.

\section{Literature Review}

A great number of the studies in teacher education still to state that teacher candidates are ill-prepared to teach with technology when they enter classrooms (Angeli \& Valanides, 2009; Ertmer \& Ottenbreit-Leftwich, 2010; Kay, 2006; Sang et al., 2010; Tondeur, Roblin, van Braak, Fisser, \& Voogt, 2013; Kashyna, 2016). Very few teacher candidates, though required, design and teach technology-based lessons (Voogt, Fisser, Roblin, Tondeur, \& van Braak, 2013). There is the need to design specific technology intergretion strategy in the courses or training programs for candidate teachers (Borthwick \& Hasen, 2917). This might be resoved through examination of professional standards of the teachers to be (Lukyanova, 2011; Tondeur, Roblin, van Braak, Fisser, \& Voogt, 2013; Kashyna, 2016). However, it is difficult to identify what techonolgy-related knowledge the instructors should gain and what efferts to make to support them (Kashyna, 2016; Borthwick \& Hasen, 2917).

\section{Method}

This study focused on empirically testing the model assessment of instructors' technology competency to be used in the settings of formal and non-formal education and uses a variety of general theoretical, empirical and statistical methods to conduct the empirical experimental study of the problem of the diagnosis of the professional competence of the teaching staff in the use of educational technologies in formal and non-formal education settings.

\subsection{Research Procedure}

The study continued for two years and was splitted into stages: analytical and experimental.

Analytical stage of the research (gap-to-study specification, feasibility validation, goals setting, selection of methods and experimental tools) lasted from 2016 to 2017. This stage involved the following research activities: (1) analytical study of the extend to which the research problem has been explored, theoretical and comparative review of domestic and foreign best practices in assessing the state of formation of professional competence of pedagogical staff in the use of educational technologies in the settings of formal and non-formal education; (2) specification of the conceptual and categorical structure of our research; formulation of the hypothesis, goals and objectives of the study; (3) attribute the methodological principles to diagnostic assessment of professional competence of pedagogical staff 
regarding the use of educational technologies in the conditions of formal and non-formal education.

Experimental (confirmatory) stage of research lasted for 2017-2018. This stage focused on taking several steps like to verify the hypothesis through the experiment, to specify the structure of the professional competence of the teaching staff in the use of teaching technologies in formal and non-formal education, which consists of the components below: axiological and regulatory, concept and content-based, praxeologically reflexive. There were specified the criteria (value-based and conative, cognitive, action-based and reflexive), their indicators and levels of formation (imitative and reproductive, interpretative and activity-based, innovative and interactive). It was carried out mathematical processing of received information. Data validation was performed on proving validity (significance). There have been drawn the conclusions and formulated prospects for further scientific researches on the problem of diagnostic assessment of professional competence of pedagogical staff concerning the use of teaching technologies in the settings of formal and non-formal education.

\subsection{Methodology of Specifying the Criterea}

To identify of dimensions of instructors' technology competency to be used in the settings of formal and non-formal education, the systematic search and selection of related papers for the qualitative analysis was fulfilled.

The search was Scopus, Civilica, SID, IRANDOC, and ISC science databases, and also the Google scholar specialized database over the recent 20 years. The key words for the search included a combination of 'components/instructors' technology competency', 'necessary actions of instructors in computer-mediated environment', 'competency structure for instructors using technology in formal and non-formal education'. 105 papers were found appropriate judging by title, abstract, content and quality of the paper; finally, 13 papers and reports containing different competency structures were selected to be examined for different components of the intructor's technology competency.

The validity of the components of the intructor's technology competency was confirmed by 7 experts. While designing the assessment model, the criteria of previous models were taken as codes, and considering semantic similarity of the codes, they were combined to create new concepts. Further on, the Intercoder Agreement method was used to assess the reliability of the assessment (criteria-based) model; to do so, a second researcher should code the text independent from the first one; similarity of the work of both researchers would be the sign of a high reliability. Kappa coefficients were used to measure the agreement between the two coders. The obtained value of the coefficient was 0.85 ; the value falls between 0.81 and 1 , which is indicative of a high agreement.

To substantiate the general methodology of studying this problem, it is important to shape the author's approach to the interpretation of the notion of the professional competence of teaching personnel in the use of teaching technologies in formal and non-formal education settings. We have defined this phenomenon as an integrated quality of an instructor (teacher) that serves as the basis for the value-determined and motivational orientation of their personality to innovate in their instructional activity which involves understanding the specifics of the organization of formal and non-formal learning, the ability to conduct research along with performing organizational and communicative skills in the process of adapting domestic and foreign experience of the use of learning technologies and the development of original technologies. The above describes the person who is characterized by a high degree of pedagogical reflection on their results of teaching and learning, by the need for self-improvement and self-development in the use of educational technology.

Having revealed the structure of the phenomenon under investigation, the components of the professional competence of teaching personnel were specified. They were as follows: axiological and regulatory, concept and content-based, praxeologically reflexive components. The axiological and regulatory one provides for the completed formation of motives and needs to use teaching technologies in formal and non-formal education settings, existence of value orientations in the awareness of the need to use innovative forms, methods, innovative educational technologies in teaching, pedagogical activities accompanied by striving for development of personal and professional qualities of the person to meet the requirements to the specialists on the current labour market. The concept and content-based component denotes the level of knowledge of the theory and its practical application to the use of teaching technology in formal and non-formal education settings; it addresses the teacher's awareness of the step-by-step integration of teaching technologies, their classification, structure, psychological and pedagogical bases of modelling of the process of introduction of educational technologies in the formal and non-formal context of the organization of the educational process, it deals with the working knowledge of a thesaurus on the problem of the design and use of original learning technologies, the systematic use of thesaurus in their professional activities. The praxeologically reflexive component supposes the use of a range of relevant skills, abilities enabling the effectiveness of the creative use of existing learning technologies (dissemination) and the development of original technologies 
(innovations); command of organizational skills, which involves the ability to design the process of using teaching technology for different categories of learners (pupils, students, adults), to implement stages of technology introduction through the teaching of a certain discipline, apply different forms and methods of training; performance of the research skills that supposes processing, retransmission of currently employed learning technologies used in Ukrainian or abroad, the ability to pedagogical reflection which determines the teacher's ability of self-analysis, self-assessment of the use of teaching technologies in formal and non-formal education, the focus on self-improvement in the creative use of the original educational technologies and the development of their own ones, taking into account the needs, value orientations, motives of those who learn.

Based on the analysis of the structure of the occupational competence of the pedagogical staff in the use of technology in the settings of formal and non-formal learning, we have specified the criteria and levels of proficiency of the pedagogical staff in the use of technology, namely: a value-based and conative criterion which addresses teacher's motivation, needs, value-based attitude of a teacher to the use of teaching technologies of different types in the formal and non-formal education settings. This criteria refers to the needs for self-improvement in the direction of using and developing educational technologies, determines the level of activity in terms of mastering the knowledge of the theory and practice of teaching the use of technology, taking into account age, psychological characteristics, personal and professional needs of different categories of those who study. The need for professional self-development in using educational technologies is a need of a value-based type, which determines the necessity to improve the relevant skills, adapt the experience of implementing proper technologies in the domestic and foreign discourse of educational practice. The indicators of value-motivational criterion are motivation and value-based orientations regarding the use of educational technologies in formal and non-formal education.

The cognitive criterion defines the level of knowledge of the theory and practice of using educational technologies to teach different categories of learners (pupils, students and adults) based on domestic and international best practices; it deals with the teachers' awareness of the specifics of teaching different categories of learners in formal and non-formal education settings; awareness of scientific approaches, principles, patterns of designing original technologies as well as their structure, stages of implementation, forms and methods which shape the procedural unit of educational technology design; awareness of methodological approaches that determine the conceptual block of modelling a particular technology of teaching; awareness of the structural components of pedagogical proficiency which ensure the effectiveness of the integration of technology (external and internal speech technology, pedagogical tact, humanistic purpose of learning, etc.). Indicators of the criterion are defined to be awareness of the theory of the design and use of teaching technology in formal and non-formal education settings; awareness of domestic and foreign best practices in the design and application of teaching technologies in formal and non-formal education settings. The action-based and reflexive criterion supposes the ability of a teacher to apply the educational technology in formal and non-formal education, that is, in his professional activities; it identifies the level of possession of organizational, research, communicative skills are used at, as well as pedagogical techniques in the process of using technologies to teach different categories of learners (pupils, students, adults); it addresses the teacher's ability to self-evaluate the results of their professional activity at various stages, to structure the content, to select the forms and methods of teaching certain disciplines in formal education settings or to apply effective forms, methods, technologies of teaching in the settings of non-formal education, taking into account principles, regularities, approaches to educating different categories of people.

This criterion determines the teacher's ability to self-develop professionally on the basis of reflexive rethinking of domestic and foreign experience and the ability to evaluate the achievements and drawbacks of using technology in their own teaching activities and in those of their colleagues. It allows identifying the ability to respond flexibly to innovations in educational and scientific environments through professional self-development and self-realization performed on reflexive principles. The indicators of action-based and reflexive criterion are as follows: application of the skills of creative use of the developed technologies (dissemination) and creation of original technologies (innovations); pedagogical reflection (ability to self-examine and intentions to self-develop and self-improve regarding the use of teaching technologies in the settings of formal and non-formal education).

Based on the above outlined criteria and indicators of the professional competence of the teaching personnel regarding the use of educational technologies in formal and non-formal education, we identified the levels of formation of the professional competence of the teaching staff regarding the use of teaching technology in formal and non-formal education environment. They are as follows:

1. Imitative and reproductive level-it referes to the lowest level of instructors' ability to use educational technology in formal and non-formal education, characterized by unexpressed motivational attitudes and unclear needs for 
mastering this aspect of the competence; the unconscious need to use innovative technologies and to enrich traditional forms and methods of teaching; fragmentary awareness of the theory of the design and use of educational technologies; limited awareness of the domestic and foreign best practices of using educational technologies, inability to extrapolate this experience on their own teaching activities, taking into account the specifics of formal and non-formal learning; insufficient manifestation of research, organizational, communicative skills in the introduction of interactive, innovative forms, methods, technologies of teaching; inability for instructors to perform pedagogical reflection; lack of understanding of the importance of self-improvement in introducing innovations in teaching activity.

2. Interpretative and activity-based level-it adresseses the intermediate level of professional competence in teaching personnel to use teaching technology in formal and non-formal education settings, which is determined by formal motivational attitudes and adequately clearly defined needs for mastering their professional competence, lack of awareness of the value of the potential of educational technologies, insufficient understanding of the specifics of formal and non-formal education; awareness of the theory of the design and use of technologies of teaching through application of interpretation skills; sufficient awareness of the domestic and foreign best practices of using educational technologies, ability to extrapolate this experience on their own teaching practices at a reproductive level taking into account the specifics of formal and non-formal education; the ability to use educational technologies designed by teachers or scientists; discretion in the design of their own technologies; frequent manifestation of ability to perform pedagogical reflection, particularly for evaluating their own shortcomings on the use of learning technologies in the settings of formal and non-formal education; awareness of the importance of self-improvement in introducing innovations in instructional activity.

3. Innovative and interactive level-it refers to a high level of professional competence in teaching personnel regarding the use of teaching technology in formal and non-formal education settings, which is characterized by such manifestations as: precise motivational attitudes, professional and personal needs in mastering the technology; awareness of the need for the use of innovative technologies and the enrichment of traditional forms and methods of learning through research, familiarization with the best models of innovative pedagogical activity and the creation of their own innovations, their phased introduction, reflexive evaluation and improvement; ability to extrapolate best practices of the experts or scientists on their own teaching practices through adapting them to the specifics of the educational process, a focus group, the conditions of the educational environment; identification of the need for the design and use of their own teaching technologies, seen in the synthesized manifestation of research, organizational, communicative skills; active professional position in terms of introduction of interactive, innovative forms, methods, technologies of teaching; potency to pedagogical reflection on the evaluation of the procedure and outcomes components of the use of teaching technology in formal and non-formal education settings.

Based on the identified criteria, indicators of the professional competence of the teaching personnel in the use of educational technology in formal and non-formal education settings, there was conducted a diagnostic assessment of the extent to which this aspect of the occupational was developed competence. Given the above, there was chosen a diagnostic toolkit.

\subsection{Methodology}

This is a qualitative study. Literature review indicates that research on instructors' competencies in electronic means of teaching are mostly qualitative.

\subsubsection{Sample}

The experiment involved 185 teachers who attended the upgrade training course run by the Chernivtsi Institute of Post-Graduate Pedagogical Education, and teachers/lecturers for the Sumy State Pedagogical University named after Anton Makarenko, Pavlo Tychyna Uman State Pedagogical University, Poltava National Pedagogical University named after V.G. Korolenko, the Kiev Antonov Makarenko Vocational-Pedagogical College.

The teachers and lecturers were the study subjects. $45 \%$ of them have more than 10 years of pedagogical experience (teaching work), 32\%-up to 10 years of teaching experience; $18 \%$-more than 20 years of teaching experience. $35 \%$ of them have a title of "teacher-methodologist", while $28 \%$ have a scientific degree.

\subsubsection{Instruments}

The methodology of diagnosing the individual structure of the value orientations of the personality developed by Sergeevkova et al. (2012) and Henning's methodology called "Structure of Interests" (Bondarchuk, 2014) were used to specify the structure of the professional competence of the teaching staff in the use of teaching technologies in formal and non-formal education. "Square of Values" methodology by Murzina (2014) was used to reveal the value 
orientations of the personality. The level of development of communicative skills was tested by the card of Hordianko \& Kopets, 2011. Instructors' social values of personality and assessment of the level of self-valuation of professional pedagogical motivation were diagnosed by the methododlogy of Fetiskin, Kozlov \& Manuilov (2009) adapted and with Bass's questionnaire on orientations entitled "Personality orientations" (Bondarchuk, 2014). Modified diagnostic techniques borrowed from Semichenko called "Motives for studying at a higher educational institution" (Bondarchuk, 2014), the methodology for examination of the motivation drivers of professional activity (Mironova, 2006; Dobre, 2013) methodology of self-assessment of vocational and pedagogical motivation and Kozlov (Fetiskin, Kozlov \& Manuilov, 2009) were used to test the development of job-related motivation. The level of formadness of self-assessment of the emotional condition was tested by methodologies of Wessman and Riks (1966). Criteria Cognitive Aptitude Test (CCAT, n./d.) was used to test the instructors cognitive abilities.

The questionnaire comprised three sections. Each section was aimed at a specific criterion (see Appendix A).

\section{Results and Discussions}

While performing diagnostic assessment of the level of the competency in the use of educational technologies in formal and non-formal education, a range of adapted techniques and questionnaires designed exclusively by author were used: for the value-based and conative criterion-a questionnaire for identifying the level of motivation and needs for the use of educational technology in formal and non-formal education settings; the methodology for examination of the motivation drivers of professional activity (Mironova, 2006), "Square of Values" methodology by Murzina (2014) to reveal the value orientations of the personality; questionnaires, surveys were used to meet $a$ cognitive criterion-aimed assessment; for activity and reflexion-based-questionnaires, case-study technology, "brainstorming", the cards of expert evaluation. Table 2 presents the consolidated survey results by criteria and indicators.

Table 1. Distribution of the answers to the questionnaire consistent with the criteria and based on pedagogical work experience

\begin{tabular}{|c|c|c|c|}
\hline Less than 10 years & More than 10 years & More than 15 years & More than 20 years \\
\hline \multicolumn{4}{|c|}{ Value-based and conative criterion } \\
\hline $\begin{array}{l}\text { I've been constantly } \\
\text { self-developing on } \\
\text { myself ... } \\
\text { I have to be of interest for } \\
\text { pupils (students) ... } \\
\text { I come prepared to the } \\
\text { class } \\
\text { My pupils (students) are } \\
\text { interested in such forms } \\
\text { and methods as master } \\
\text { classes, trainings, heuristic } \\
\text { and dialogue technologies. }\end{array}$ & $\begin{array}{l}\text { I do not have a special need to } \\
\text { develop exlusive/original } \\
\text { technology because I use many } \\
\text { different forms and methods in my } \\
\text { teaching. } \\
\text { I deliver my classes using } \\
\text { Ukrainian, so I do not feel that it is } \\
\text { necessary to further develop my } \\
\text { language competence } \\
\text { I have to be of interest for pupils } \\
\text { (students)... }\end{array}$ & $\begin{array}{l}\text { I work hard, so I can hardly ever } \\
\text { employ the opportunities for } \\
\text { self-development } \\
\text { I do not use the tools of museum } \\
\text { pedagogy, because I cannot dedicate } \\
\text { time } \\
\text { I come prepared to the class } \\
\text { My pupils (students) are interested in } \\
\text { such forms and methods as master } \\
\text { classes, trainings, heuristic and } \\
\text { dialogue technologies. } \\
\text { Scientific research stimulates me to } \\
\text { develop new forms of teaching }\end{array}$ & $\begin{array}{l}\text { I do not feel the need to study the } \\
\text { experience of scientific schools, } \\
\text { because I have a different area of } \\
\text { interest } \\
\text { The passive approach of } \\
\text { management is the obstacle to me } \\
\text { to self-develop professionally, I } \\
\text { am not motivated, I am under the } \\
\text { influence of financial instability. }\end{array}$ \\
\hline
\end{tabular}

\section{The cognitive criterion}

\begin{tabular}{|c|c|c|c|}
\hline $\begin{array}{l}\text { Formal education is } \\
\text { intended for the balanced } \\
\text { development of the } \\
\text { individual, while } \\
\text { non-formal education } \\
\text { purpose is to meet personal } \\
\text { needs. }\end{array}$ & $\begin{array}{l}\text { Formal education is intended for the } \\
\text { balanced development of the } \\
\text { individual, while non-formal } \\
\text { education purpose is to meet } \\
\text { personal needs. }\end{array}$ & $\begin{array}{l}\text { The scientific and pedagogical school is } \\
\text { based on sharing experience, the } \\
\text { implementation of innovative ideas, the } \\
\text { search for optimal ways for effective } \\
\text { learning; It seems to be the source of } \\
\text { new knowledge and advancement. }\end{array}$ & $\begin{array}{l}\text { Formal education is an } \\
\text { institutionalized form of } \\
\text { education which is intended to } \\
\text { professionally and personally } \\
\text { develop an individual different } \\
\text { forms of teaching outside the } \\
\text { educational institution; }\end{array}$ \\
\hline $\begin{array}{l}\text { Technology of education is } \\
\text { the way of mastering } \\
\text { certain instructional } \\
\text { material, the way of } \\
\text { meeting a certain goal, the } \\
\text { way of mastering a subject, }\end{array}$ & $\begin{array}{l}\text { The potential of museum pedagogy } \\
\text { is mainly realized in such traditional } \\
\text { forms as excursions, presentations, } \\
\text { lectures, round table discussions, } \\
\text { meetings with artistic people. } \\
\text { The scientific and pedagogical }\end{array}$ & $\begin{array}{l}\text { Formal education is an institutionalized } \\
\text { form of education which is intended to } \\
\text { professionally and personally develop } \\
\text { an individual different forms of } \\
\text { teaching outside the educational } \\
\text { institution; without informational it is }\end{array}$ & $\begin{array}{l}\text { without informational it is } \\
\text { impossible to self-organize and } \\
\text { gain certain competencies without } \\
\text { the non-formal education. } \\
\text { Learning technology is an } \\
\text { algorithm for action in the }\end{array}$ \\
\hline
\end{tabular}




\section{topic}

Role-playing games, exercises, workshops, projects, discussions, etc. are the technologies of the development of language and communicative competence. school is based on sharing impossible to self-organize and gain experience, the implementation of innovative ideas, the search for optimal ways for effective learning; It seems to be the source of new knowledge and advancement. certain competencies without the non-formal education.

The scientific and pedagogical school is a non-formal union of scientists working for higher educational establishments, who ensure the continuity of scientific knowledge and scientific generations, along with the integration of researchers into the training process to carry out the training of scientific and pedagogical staff.

educational process, a set of methods and techniques.

The scientific and pedagogical school is a non-formal union of scientists working for higher educational establishments, who ensure the continuity of scientific knowledge and scientific generations, along with the integration of researchers into the training process to carry out the training of scientific and pedagogical staff.

Language and communication technologies are a conjunction of forms and methods aimed at mastering of the native and foreign languages in order to present the results of their own scientific activity, to carry out effective pedagogical activities in dialogue-based mode.

\section{The action-based and reflexive criterion}

I consider traditional forms and methods of teaching (lecture, seminar, practical classes, etc.) to be the mos effective.

The teacher is supposed to be motivated to develop their own linguistic culture, language and communicative competence. For this reason, the level of language proficiency is not particularly dependent on the use of either traditiona or innovative forms and methods.

Since I have no time for self-education, I upgrade myself professionally through doing the courses at the institute of postgraduate pedagogical education.

To develop the language and communicative competence of a student, I simulate the situation at each lesson using a certain interactive method: training, group work,
The commonly used organizational forms of non-formal education include excursions, work in small groups, self-education, electives, theatricalization, in-service education courses, etc.

I consider traditional forms and methods of teaching (lecture, seminar, practical classes, etc.) to be the most effective.

The teacher is supposed to be motivated to develop their own linguistic culture, language and communicative competence. For this reason, the level of language proficiency is not particularly dependent on the use of either traditional or innovative forms and methods.

I just adjust certain of the above to fit the content and methodology of the classes.

I do not use the potential of museum pedagogy, because I teach neither historical nor philological disciplines, but psychological and pedagogical.

In the selection of forms, methods, and technologies of education in the settings of formal education it is necessary to take into account the
Since I have no time for self-education, I upgrade myself professionally through doing the courses at the institute of postgraduate pedagogical education.

I see no possibility of using best practices of scientific and pedagogical schools in my work, because I have a clearly structured program, methodological recommendations, etc., which I use in my teaching work.

I just adjust certain of the above to fit the content and methodology of the classes.

I do not use the potential of museum pedagogy, because I teach neither historical nor philological disciplines, but psychological and pedagogical.

The management of an educational institution should stimulate the aspiration of teachers to the search and creativity.

I try to regularly participate in various activities that are the organizational forms of non-formal education (webinars, trainings, workshops, co-workings, etc.), I go abroad to do internships.

In the selection of forms, methods, and technologies of education in the settings of formal education it is
I see no possibility of using best practices of scientific and pedagogical schools in my work, because I have a clearly structured program, methodological recommendations, etc., which I use in my teaching work.

I just adjust certain of the above to fit the content and methodology of the classes.

The management of an educational institution should stimulate the aspiration of teachers to the search and creativity.

Among the main reasons that impede my professional self-improvement, including the fostering skills to use and design exclusive and original technologies, is the fear of being taken as silly, the tendency to conformism, the heavy workload. 


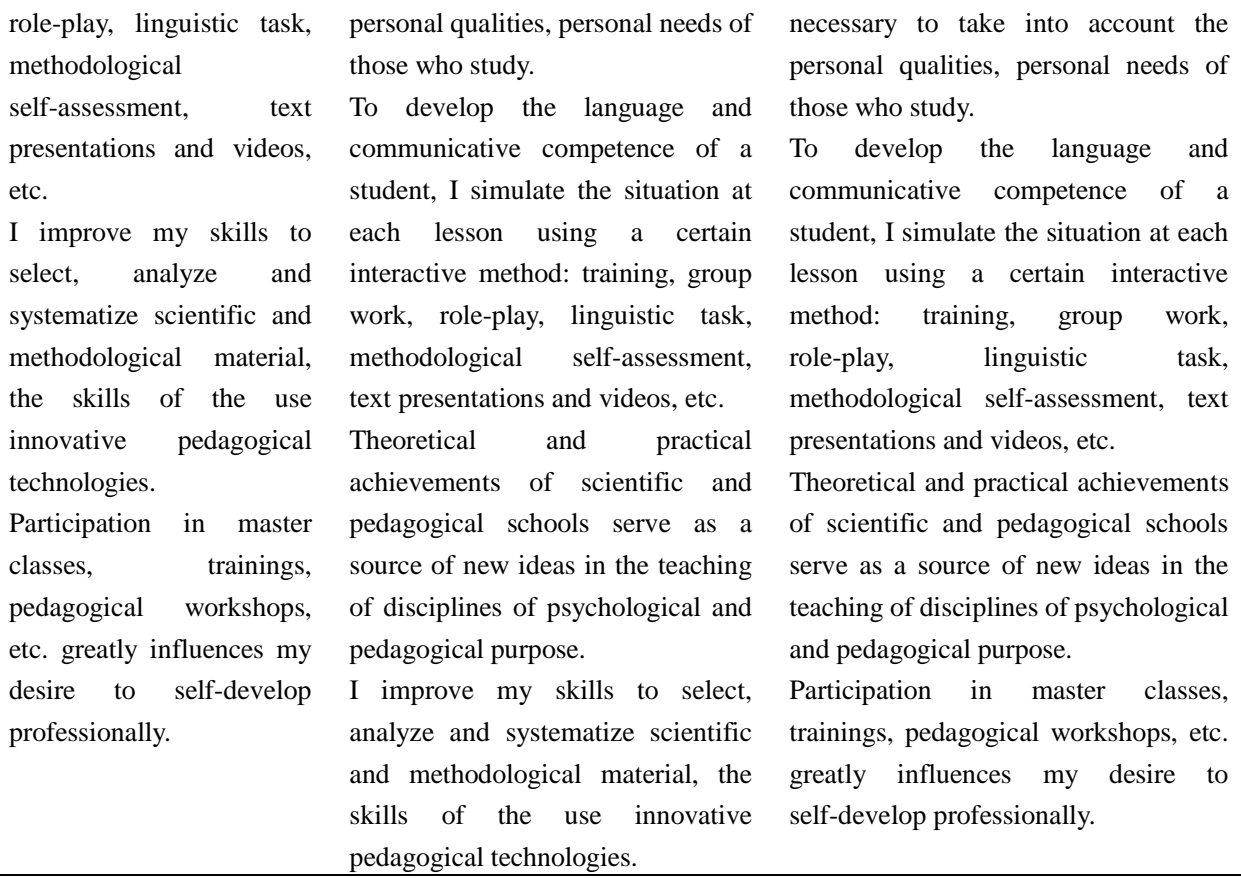

personal qualities, personal needs of those who study.

To develop the language and

communicative competence of a student, I simulate the situation at each lesson using a certain interactive method: training, group work, role-play, linguistic task, methodological self-assessment, text presentations and videos, etc.

Theoretical and practical achievements of scientific and pedagogical schools serve as a source of new ideas in the teaching of disciplines of psychological and pedagogical purpose.

I improve my skills to select, analyze and systematize scientific and methodological material, the skills of the use innovative pedagogical technologies.

necessary to take into account the personal qualities, personal needs of those who study.

To develop the language and communicative competence of a student, I simulate the situation at each lesson using a certain interactive method: training, group work, role-play, linguistic task, methodological self-assessment, text presentations and videos, etc.

Theoretical and practical achievements of scientific and pedagogical schools serve as a source of new ideas in the teaching of disciplines of psychological and pedagogical purpose.

Participation in master classes, trainings, pedagogical workshops, etc. greatly influences my desire to self-develop professionally.

Table 2. Consolidated survey results by criteria and indicators

\begin{tabular}{ccccccc}
\hline \multirow{2}{*}{ Criterion } & \multicolumn{5}{c}{ Level of competence manifestation } \\
\cline { 2 - 7 } & \multicolumn{2}{c}{ Imitative and reproductive } & Interpretative and activity-based & Innovative and interactive \\
\cline { 2 - 7 } & $N$, respondents & $\%$ & $N$, respondents & $\%$ & $N$, respondents & $\%$ \\
\hline Value-based and conative & 38 & $20 \%$ & 82 & $44 \%$ & 55 & $24 \%$ \\
Cognitive & 51 & $28 \%$ & 76 & $41 \%$ & 58 & $31 \%$ \\
Action-based and reflexive & 49 & $26 \%$ & 75 & $40 \%$ & 61 & $33 \%$ \\
\hline
\end{tabular}

We emphasize the indicative results of diagnostic assessment of the level of the above-specified competence consistent with the criteria.

While determining the level of value-based and conative criterion of professional competence of pedagogical staff regarding the use of adult educational technologies in formal and non-formal education, we identified the below motives, needs and values in a teacher:

1. perception of necessity for professional self-development, constant self-improvement in accordance with educational needs (25\%-imitative and reproductive, 53\%-interpretative and activity-based, $12 \%$-innovative and interactive level);

2. the need for the development of language and communicative competence (18\%-imitative and reproductive, 49\%-interpretative and activity-based, 33\%-innovative and interactive level);

3. the need to use innovative technologies, forms and methods (16\%-imitative and reproductive, $61 \%$-interpretative and activity-based, 23\%-innovative and interactive level);

4. motivation to use scientific achievements in the professional activity, achievements of scientific and pedagogical schools (22\%-imitative and reproductive, 48\%-interpretative and activity-based, 30\%-innovative and interactive level);

5. pursuance of the development of orginal/exclusive technologies, creation of innovations (17\%-imitative and reproductive, 52\%-interpretative and activity-based, 31\%-innovative and interactive level);

6. perception of functions of museum pedagogy and its use in educational practice (25\%-imitative and reproductive, 54\%-interpretative and activity-based, $21 \%$-innovative and interactive level).

The below bar chart (Figure 1) provides the consolidated responses of teachers, who mainly showed the imitative and reproductive, and interpretative and activity-based levels of the studied competence according to the value-based and conative criterion. 
Based on the responses of teachers aimed at identifying the level of the studied competence assessed by the cognitive criterion, we found that they do well in the below:

1. they interpret the notion of "technology of learning" as a combination of traditional and innovative forms and methods of teaching used within the educational process in general, the putting into practice an educational program, of an educational discipline, in order to obtain a specified outcome (15\%-imitative and reproductive, $44 \%$-interpretative and activity-based, $41 \%$-innovative and interactive level);

2. they define the technologies of formal education as a systemically organized learning process, carried out in different types of educational institutions (30\%-imitative and reproductive, 27\%-interpretative and activity-based, $43 \%$-innovative and interactive level);

3. they define the technologies of non-formal education as a set of forms and methods of instruction that are applied within and outside of educational institutions and are accessible to persons of any age for the purpose of meeting educational needs (19\%-imitative and reproductive, 38\%-interpretative and activity-based, 43\%-innovative and interactive level);

4. they are familiar with the most widely used education technologies in formal and non-formal education settings (personality-oriented, developing, technology of educational training, technology of critical thinking development, creative development, task-based teaching, etc.) (25\%-imitative and reproductive, 54\%-interpretative and activity-based, $21 \%$-innovative and interactive level);

5. they perceive the need for combination of formal, non-formal and non-formal education for the purpose of professional and personal development of the various categories of those who are taught (14\%-imitative and reproductive, $41 \%$-interpretative and activity-based, $45 \%$-innovative and interactive level);

6. they define the notion of "scientific and pedagogical school" as a non-formal union of scientists, teachers aimed at developing the ideas of a scientific leader and the use of shared research experience in educational practice (19\%-imitative and reproductive, 28\%-interpretative and activity-based, 53\%-innovative and interactive level);

7. among the technologies of development of language and communicative competence there are distinguished the most commonly used (dialogue-based training, training, project design-based, etc.) (22\%-imitative and reproductive, 39\%-interpretative and activity-based, 39\%-innovative and interactive level);

8. teachers distinguish demonstration, real and virtual excursion, projects, lesson-exhibition, "immersion" in the historical epoch, method of reconstruction of events, etc. among the forms, methods and technologies of museum pedagogy (36\%-imitative and reproductive, 24\%-interpretative and activity-based, $40 \%$-innovative and interactive level).

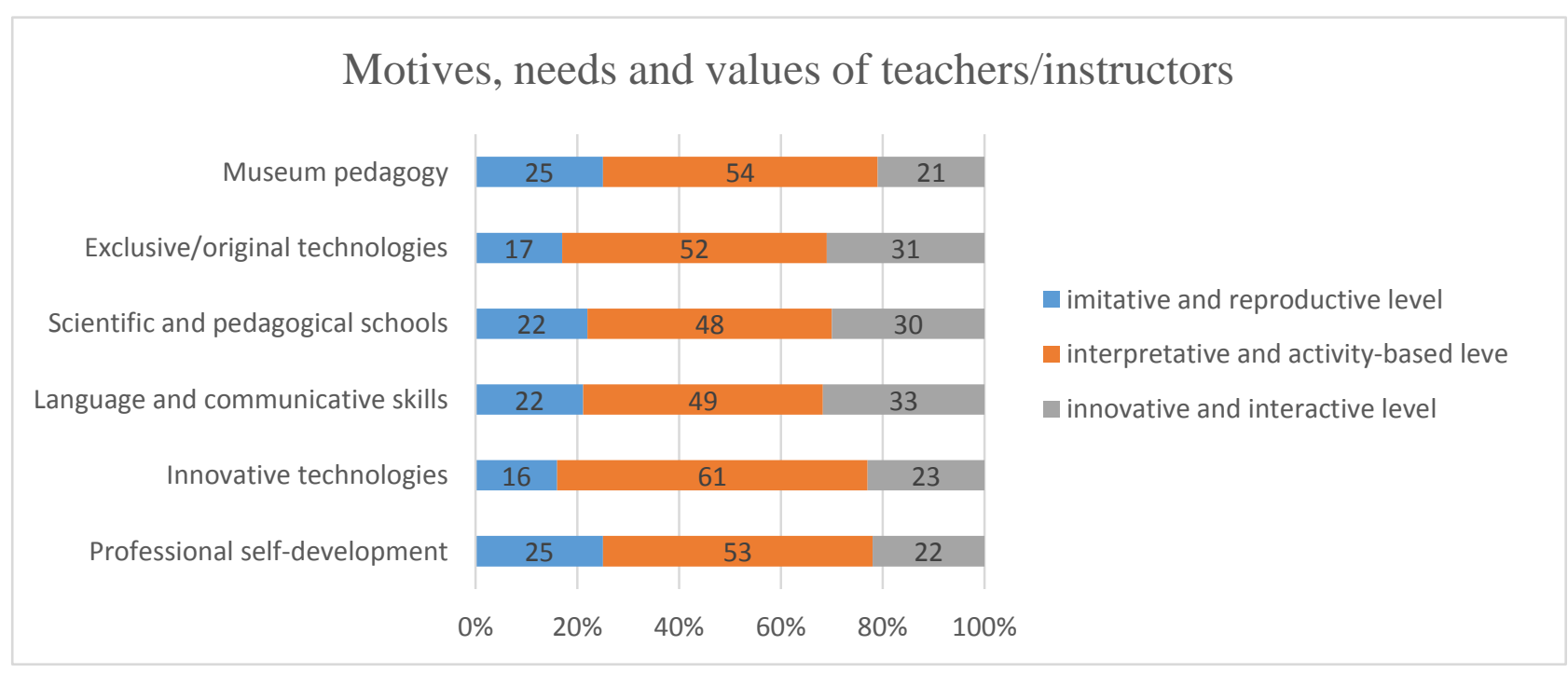

Figure 1. The use of adult educational technologies in formal and non-formal education by teachers (determined levels by value-based and conative criterion)

It is necessary to note that overall the responses of the teaching staff to the questionnaires and surveys indicate that the prevailing of interpretative and activity-based, and innovative and interactive levels of manifestation of 
competence under the study (see Figure 2 below).

As a result of doing the survey, questionnaires, and the use of adapted diagnostic tools, we determined the levels of professional competence of pedagogical staff regarding the use of learning technologies in formal and non-formal education according to the action-based and reflexive criterion.

The analysis of answers implies the prevailing of imitative and reproductive та interpretative and activity-based levels of the majority of the teachers/instructors.

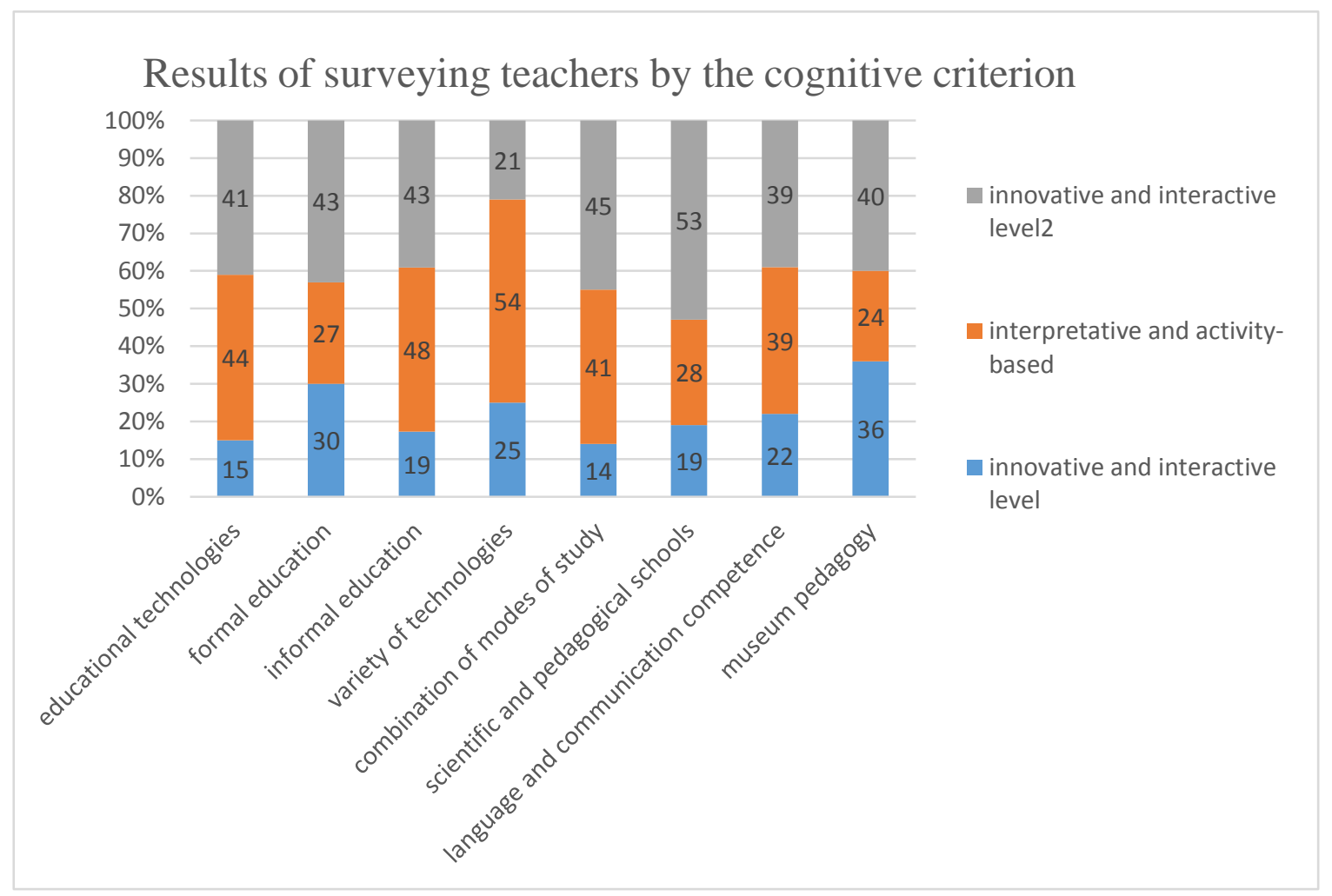

Figure 2. The use of adult educational technologies in formal and non-formal education by teachers (determined levels by cognitive criterion)

If we project the experience of teachers with regard to performing the research, communicative, organizational skills combined with the ability to pedagogical reflection that allow for innovation, flexible adaptation of well-known teaching technologies in formal and non-formal education and design original/exclusive technologies, we can determine the levels of manifestation of the competence under the study which are correlated with answers of the respondents:

1. training sessions, problem seminars, participation in conferences, webinars, video collections, etc. are among the commonly used organizational forms of non-formal education (29\%-imitative and reproductive, $45 \%$-interpretative and activity-based, $26 \%$-innovative and interactive level);

2. the use of interactive, innovative forms, methods and technologies of learning in formal education envisages the use of training technologies, "brainstorming", role-playing games, quests, problem-solving analysis, case-technology (41\%-imitative and reproductive, $25 \%$-interpretative and activity-based, 34\%-innovative and interactive level);

3. projects, the cross-curriculum structuring of the content of linguistic disciplines, simulation the situations of success, linguistic games, "brainstorming", secants, the method of unfinished sentences, etc. are considered the effective forms and methods of fostering language and communicative competence (38\%-imitative and reproductive, $39 \%$-interpretative and activity-based, $27 \%$-innovative and interactive level);

4. the teachers most often use the materials of periodicals, electronic libraries, scientific literature in order to improve their skills to use of innovative forms, methods, technologies of teaching (18\%-imitative and reproductive, $25 \%$-interpretative and activity-based, 57\%-innovative and interactive level); 
5. best practices of scientific and pedagogical schools should be used in the process of training of specialists, and for the purpose of professional and personal development (46\%-imitative and reproductive, 34\%-interpretative and activity-based, 20\%-innovative and interactive level);

6. an important direction for improving professional competence is the use of innovative experience, the adaptation of foreign technology to the settings of the domestic educational process, the development of original/exclusive programs (42\%-imitative and reproductive, 33\%-interpretative and activity-based, 25\%-innovative and interactive level);

7. use of the potential of museum pedagogy in the settings of formal and non-formal education, which involves the use of traditional and non-traditional forms, methods, technologies (lesson-research, lecture-discussion, exhibition, excursion, technology of flipped classroom, etc.) (51\%-imitative and reproductive, $32 \%$-interpretative and activity-based, $17 \%$-innovative and interactive level);

8. the development of professional competence will facilitate the conditions for sharing work experience, acquaintance with instructional findings of teachers (master-classes, pedagogical workshops), the development of effective technologies, the introduction of training programs, conducting exclusive/original workshops, etc. (27\%-imitative and reproductive, 31\%-interpretative and activity-based, $42 \%$-innovative and interactive level);

9. accepting the need for professional self-development in using commonly used technologies of teaching and developing exclusive/ original technologies (25\%-imitative and reproductive, 38\%-interpretative and activity-based, $37 \%$-innovative and interactive level).

Figure 3 below provides the visualized results of the evaluation of the use of adult educational technologies in formal and non-formal education by teachers (determined levels by to the action-based and reflexive criterion).

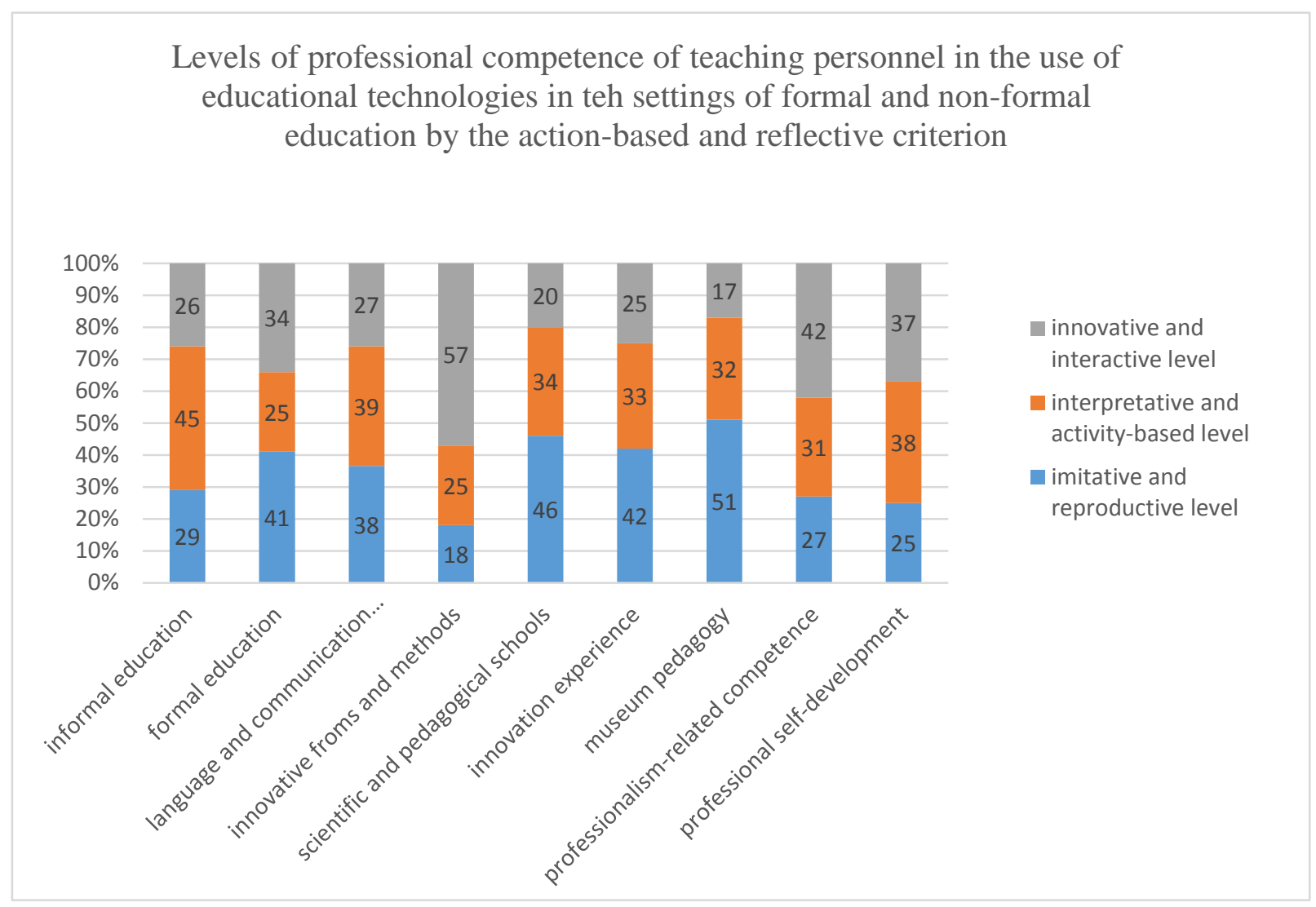

Figure 3. The use of adult educational technologies in formal and non-formal education by teachers (determined levels by to the action-based and reflexive criterion)

As the above data suggests, individuals felt the educational technologies could be useful for transforming educators' teaching practice as well as lesson design, and noted the integration of the educational technologies could be effective, transformational pedagogical practices. After the assessment, many individuals reported they would be 
inspired by the perspective to deliver their classes through a computer-mediated means, which, they are sure, would promote growth and change as well as their students' achievements.

\section{Conclusion}

Enhancement of teaching and learning using educational technologies by the instructor requires a transformation in the teaching process and, as a result, activities of the instructors. When teahing through a computer-mediated environment, the instructor pays more effort to motivate and guide their learnirs than to transfer knowledge. For this reason it is a necessity to review the instructors technology competency; this competency is related to the duties of the instructor, the functional features of the environment where they present this competency, and the available technology. Consequently, it is essential to explain and specify the criteria of assessing the technological competency of a teacher, and the objective of this study is to present a comprehensive list criteria and indicators of a teacher's technological competency to be used in formal and non-formal education settings.

Thus, according to the results of the diagnostic assessment of the levels of professional competence of the teaching staff regarding the use of educational technology in formal and non-formal education settings on the basis of the developed criteria and indicators, it was found that, despite the fact that a significant part of the teaching staff demonstrated imitative and reproductive level of the competence by all the criteria, we consider it expedient to note that the majority of the teachers are focused on self-development and self-improvement in terms of using educational technologies in formal and non-formal education settings. They show a desire to adapt foreign and domestic best practices in implementing these technologies, they are capable for the pedagogical reflection, accept the need for implementing innovation in the teaching process. Educational authorities should provide the teacher training programs aimed at developing needed skills and attitudes (competency) to use technology in the settings of formal and non-formal education settings.

\section{Limitation and Study Forward}

It can be the prospect of further research to study how to develop and introduce education technologies for various categories of adults into formal and non-formal education settings (technology of development of technological competence of teaching staff, technology for the development of innovative thinking of teachers, technology for the development of language and communicative competence of a teacher-researcher, etc.), which will promote the development of professionalism level of pedagogical staff taking into account modern requirements and the needs of the labour market.

\section{Acknowledgments}

We are thankful to all contributors to this research us so that we could smoothly complete it.

\section{References}

Aljaberi, N. M. (2015). The Competence of Teachers Embedded in the Classroom and Child Education Programs in Jordan, and It's Compatibility with the Required Competence of Teacher in the Age of Information Technology. American Journal of Educational Research, 3(7), 32-43.

Angeli, C. \& Valanides, N. (2009). Epistemological and methodological issues for the conceptualization, development, and assessment of ICT-TPCK: Advances in technological pedagogical content knowledge (TPCK). Computers \& Education, 52(1), 154-168. https://doi.org/10.1016/j.compedu.2008.07.006

Anishchenko, O. (2011). Adult Education Technologies. Retrieved from http://lib.iitta.gov.ua/7699/1/\%D0\%90\%D0\%BD\%D1\%96\%D1\%89\%D0\%B5\%D0\%BD\%D0\%BA\%D0\%BE_ \%20\%D0\%A2\%D0\%B5\%D1\%85\%D0\%BD\%D0\%BE\%D0\%BB\%D0\%BE\%D0\%B3\%D1\%96\%D1\%97\%20 \%D0\%BD\%D0\%B0\%D0\%B2\%D1\%87\%D0\%B0\%D0\%BD\%D0\%BD\%D1\%8F.pdf.

Bidabadi, N. S., Isfahani, A. N., Rouhollahi, A. \& Khalili, R. (2016). Effective Teaching Methods in Higher Education: Requirements and Barriers. Journal of Advances in Medical Education \& Professionalism, 4(4), 170-178. (PMID:27795967 PMCID: PMC5065908)

Bondarchuk, O. (Ed.) (2014). Methodology of studying the features of psychological readiness of the heads of educational organizations to work in conditions of change (in Ukrainian). Kyiv.-148 p. Retrieved from: http://umo.edu.ua/images/content/institutes/cipo/kaf_psiholog/3_\%D0\%9A\%D0\%BE\%D0\%BC\%D0\%BF\%D0 \%BB\%D0\%B5\%D0\%BA\%D1\%81_\%D0\%BC\%D0\%B5\%D1\%82\%D0\%BE\%D0\%B4\%D0\%B8\%D0\%BA_\% D0\%9D\%D0\%94\%D0\%A0_\%D0\%91\%D0\%BE\%D0\%BD\%D0\%B4\%D0\%B0\%D1\%80\%D1\%87\%D1\%83\% D0\%BA_2012-2014.pdf 
Borthwick, A. C. \& Hansen, R. (2017). Digital Literacy in Teacher Education: Are Teacher Educators Competent? Journal of Digital Learning in Teacher Education, 33(2), 46-48. https://doi.org/10.1080/21532974.2017.1291249

Bošković, G. (2016). Andragogical Education-the basis for successful work in adult education. Retrieved from https://ec.europa.eu/epale/en/blog/andragogical-education-basis-successful-work-adult-education-0.

Cheng, M. (2016). Quality in Higher Education: Developing a Virtue of Professional Practice. Retrieved from https://www.sensepublishers.com/media/2877-quality-in-higher-education-1.pdf. https://doi.org/10.1007/978-94-6300-666-8

Criteria Cognitive Aptitude Test (CCAT). (n./d.). Criteria Pre-employment: Testing. Retrieved from https://www.criteriacorp.com/solution/ccat.php.

Dobre, O. I. (2013). Employee motivation and organizational performance. Review of Applied Socio-Economic Research, 5(1), 53-60.

Essays, UK. (2018). Smart Classroom in Indian Education Scenario Education Essay. Retrieved from https://www.ukessays.com/essays/education/smart-classroom-in-indian-education-scenario-education-essay.php ?vref $=1$.

European Commission. (2018). European ideas for better learning: the governance of school education systems. The final report and thematic outputs. Retrieved from https://www.schooleducationgateway.eu/downloads/Governance/2018-wgs6-Full-Final-Output.pdf.

Exam Planning. (2019). Types of Education: Formal, Informal \& Non-formal. Retrieved from https://examplanning.com/types-education-formal-informal-non-formal/.

Fetiskin, N. P., Kozlov, V. V. \& Manuilov, G. M. (2009). Socio-psychological diagnostics of the development of personality of small groups (in Russian). Moscow: Psychotherapy.-339p. Retrieved from http://ural-education.ru/wp-content/uploads/2016/12/\%D0\%9A\%D0\%BE\%D0\%B7\%D0\%BB\%D0\%BE\%D0\% B2-\%D0\%92.\%D0\%92.-\%D0\%A1\%D0\%BE\%D1\%86\%D0\%B8\%D0\%B0\%D0\%BB\%D1\%8C\%D0\%BD\%D0 $\% \mathrm{BE}-\% \mathrm{D} 0 \% \mathrm{BF} \% \mathrm{D} 1 \% 81 \% \mathrm{D} 0 \% \mathrm{~B} 8 \% \mathrm{D} 1 \% 85 \% \mathrm{D} 0 \% \mathrm{BE} \% \mathrm{D} 0 \% \mathrm{BB} \% \mathrm{D} 0 \% \mathrm{BE} \% \mathrm{D} 0 \% \mathrm{~B} 3 \% \mathrm{D} 0 \% \mathrm{~B} 8 \% \mathrm{D} 1 \% 87 \% \mathrm{D} 0$ $\% \mathrm{~B} 5 \% \mathrm{D} 1 \% 81 \% \mathrm{D} 0 \% \mathrm{BA} \% \mathrm{D} 0 \% \mathrm{~B} 0 \% \mathrm{D} 1 \% 8 \mathrm{~F}-\% \mathrm{D} 0 \% \mathrm{~B} 4 \% \mathrm{D} 0 \% \mathrm{~B} 8 \% \mathrm{D} 0 \% \mathrm{~B} 0 \% \mathrm{D} 0 \% \mathrm{~B} 3 \% \mathrm{D} 0 \% \mathrm{BD} \% \mathrm{D} 0 \% \mathrm{BE} \% \mathrm{D}$ $1 \% 81 \% \mathrm{D} 1 \% 82 \% \mathrm{D} 0 \% \mathrm{~B} 8 \% \mathrm{D} 0 \% \mathrm{BA} \% \mathrm{D} 0 \% \mathrm{~B} 0-\% \mathrm{D} 1 \% 80 \% \mathrm{D} 0 \% \mathrm{~B} 0 \% \mathrm{D} 0 \% \mathrm{~B} 7 \% \mathrm{D} 0 \% \mathrm{~B} 2 \% \mathrm{D} 0 \% \mathrm{~B} 8 \% \mathrm{D} 1 \% 82 \% \mathrm{D} 0$ $\% \mathrm{~B} 8 \% \mathrm{D} 1 \% 8 \mathrm{~F}-\% \mathrm{D} 0 \% \mathrm{BB} \% \mathrm{D} 0 \% \mathrm{~B} 8 \% \mathrm{D} 1 \% 87 \% \mathrm{D} 0 \% \mathrm{BD} \% \mathrm{D} 0 \% \mathrm{BE} \% \mathrm{D} 1 \% 81 \% \mathrm{D} 1 \% 82 \% \mathrm{D} 0 \% \mathrm{~B} 8-\% \mathrm{D} 0 \% \mathrm{~B} 8-\% \mathrm{D}$ 0\%BC\%D0\%B0\%D0\%BB\%D1\%8B\%D1\%85-\%D0\%B3\%D1\%80\%D1\%83\%D0\%BF\%D0\%BF.pdf

Gerstein, J. (2012). User Generated Education: Flipped Classroom: The Full Picture for Higher Education. Retrieved from https://usergeneratededucation.wordpress.com/2012/05/15/flipped-classroom-the-full-picture-for-higher-educati on/.

Gu, L., Jiao, J., Wang, X., Jia, Y., Qin, D. \& Lindberg, J. (2012). Case Studies on the Use of Technology in TPD (Teacher Professional Development). US-China Education Review A3, 278-290. Retrieved from https://files.eric.ed.gov/fulltext/ED532919.pdf.

Henschke, J. (2014). Andragogical Curriculum for Equipping Successful Facilitators of Andragogy in Numerous Contexts. $\quad$ Retrieved from https://trace.tennessee.edu/cgi/viewcontent.cgi?referer=https://www.google.com/\&httpsredir=1\&article=1392\& context=utk_IACE-browseall.

Hordianko, V. \& Kopets, L. (2011). Methodology approaches to designing dialogue space. Scientific Bulletin of NaUKMA. Series of Pedagogical, psychological sciences and social work, 123, 44-49.

Kashyna, G. (2016). Development of information competence of the teacher technology in postgraduate education. Intercultural Communication, 1(1), 140-154.

Kay, R. H. (2006). Evaluating strategies used to incorporate technology into preservice education: A review of the literature. Journal of Research on Technology in Education, 38(4), 383-408. https://doi.org/10.1080/15391523.2006.10782466

Kononets, M. O. (Comp.). (2017). A workbook for self-study for the students of all specialities dull-time and part-time forms of study. Kyiv: KPI named after Igor Sikorsky.

Lukyanova, L. B. (2011). Concept of adult education in Ukraine. Nizhyn: PP Lysenko M.M. 
Maksimović, J. \& Dimić, N. (2016). Digital technology and teachers' competence for its application in the classroom. Research in Pedagogy, 6(2), 59-71. https://doi.org/10.17810/2015.35

Masino, S. \& Niño-Zarazúa, M. (2016). What works to improve the quality of student learning in developing countries? International Journal of Educational Development, 48, 53-65. https://doi.org/10.1016/j.jjedudev.2015.11.012

McCauley, K. D., Hammer, E. \& Hinojosa, A. S. (2017). An Andragogical Approach to Teaching Leadership. Management Teaching Review, 2(4), 312-324. https://doi.org/10.1177/2379298117736885

Mironova, E. E. (Comp.). (2006). Motivation of professional activity (method K. Zamfir in the modification A. A. Rean). Retrieved from http://www.miu.by/kaf_new/mpp/102.pdf.

Murzina, O. A. (2014). Research of professional values based on methods "Square of values". Pedagogy of higher and secondary education, 41, 341-346.

Omidina, S., Masrom, M. \& Selamat, H. (2013). An Examination of the Concept of Smart School: An Innovation to Address Sustainability. Retrieved from https://www.researchgate.net/publication/266643401_An_Examination_of_the_Concept_of_Smart_School_An _Innovation_to_Address_Sustainability. https://doi.org/10.2991/cse.2013.73

Palis, A. \& Quiros, P. (2014). Adult Learning Principles and Presentation Pearls. Middle East African Journal of Ophthalmology, 21(2), 114-122. https://doi.org/10.4103/0974-9233.129748

Serdyukov, P. (2017). Innovation in education: what works, what doesn't, and what to do about it? Journal of Research in Innovative Teaching \& Learning, 10(1), 4-33. https://doi.org/10.1108/JRIT-10-2016-0007

Sergeenkova, O., Stolyarchuk, O., Kokhanova, O. \& Pasekova, O. (2012). General Psychology: Teaching manual. Kyiv: Center for Educational Literature. https://doi.org/10.1108/JRIT-10-2016-0007

Sang, G., Valcke, M., van Braak, J. \& Tondeur, J. (2010). Student teachers'thinking processes and ICT integration: Predictors of prospective teaching behaviors with educational technology. Computers \& Education, 54(1), 103-112. https://doi.org/10.1016/j.compedu.2009.07.010

Takeuchi, N., Mori, T., Suzukamo, Y. \& Izumi, S.-I. (2016). Integration of Teaching Processes and Learning Assessment in the Prefrontal Cortex during a Video Game Teaching-learning Task. Frontiers in Psychology, 7, 2052. https://doi.org/10.3389/fpsyg.2016.02052

Tondeur, J., Roblin, N. P., van Braak, J., Fisser, P. \& Voogt, J. (2013). Technological pedagogical content knowledge in teacher education: In search of a new curriculum. Educational Studies, 39(2), 239-243. https://doi.org/10.1080/03055698.2012.713548

Vero, E., \& Puka, E. (2017). The Importance of Motivation in an Educational Environment. Formazione \& Insegnamento, 15(1), 57-66.https://pdfs.semanticscholar.org/6e3e/f5d1c5666f3cee72ae0ddca5ef096ada5277.pdf https://doi.org/10.1111/j.1365-2729.2012.00487.x

Voogt, J., Fisser, P., Pareja Roblin, N., Tondeur, J. \& van Braak, J. (2013). Technological pedagogical content knowledge-a review of the literature. Journal of Computer Assisted Learning, 29(2), 109-121. http://dx.doi.org/10.1111/j.1365-2729.2012.00487.x

Werakula, N., Pathumcharoenwattanaa, W. \& Amatayakula, K. (2014). The main components of a non-formal education program using neo-humanist moral principles to enhance ethics in caring the elderly for the foreseen aging society. Procedia-Social and Behavioral Sciences, 152, 903-910. https://doi.org/10.1016/j.sbspro.2014.09.341

Wessman, A. E. \& Ricks, D. F. (1966). Mood and personality. New York: Holt, Rinerhart, and Winston. 


\section{Appendix A}

\section{Criterion-based Questionnaire}

\section{Value-based and conative criterion}

1. Would you like to learn more about adult education technology used in formal education? What are your reasons?

2. Do you have the desire to enrich your knowledge on the use of adult educational technologies in non-formal education settings? Why?

3. Do you feel it is necessary for you to improve your own erudition regarding the use of modern educational technologies in pedagogical activities?

4. Would you like to update and expand the conceptual apparatus, deepen your theoretical knowledge, improve practical skills of working with innovative pedagogical technologies, in particular adult education technologies? Necessary to emphasize.

5. Are you interested in developing students' language and communicative competence, their linguistic culture (students, future teachers) by introducing author-created techniques, technologies? Explain your reasoning.

6. Do you feel it is necessary to raise the level of language and communicative competence with the use of educational technologies? Explain your reasoning.

7. Are you willing to study best practices of Ukrainian scientific and pedagogical schools in order to use it creatively in your professional activity? Explain your reasoning.

8. Would you like to learn more about the methods, forms, technologies of museum pedagogy? Explain your reasoning.

9. Would you like to develop your own andragogical competence? Explain your reasoning.

10. Do you have a persistent desire to teach various categories of adults (to participate in professional development of teachers, to train future teachers, to develop various forms, methods, technology of teaching in non-formal education settings, etc.)? Justify your answer, please.

The cognitive criterion

1. How do you interpret the notion of «educational technology»?

2. Suggest your interpretation of the concept of «formal education».

3. Justify the notion of «non-formal education».

4. What is the difference between methodology of subject-based teaching and pedagogical technology?

5. What educational technologies do you use in your professional activity? Give the names of the technology developers.

6. What the pedagogical technologies of adult education are you aware of?

7. What is the specificity of the andragogical approach to learning technologies?

8. What is the essence of the teacher's andragogical competence?

9. Which mode of education (formal, non-formal, non-formal), in your opinion, is the most effective? Justify the answer.

10. What training technologies are you aware of?

11. Suggest your explanation to the concept of «scientific and pedagogical school».

12. Name the modern technologies, forms, methods of development of language and communicative competence of specialists.

13. What forms, methods, technologies of museum pedagogy are you aware of?

The action-based and reflexive criterion

1. Name the forms and methods of non-formal education used in the institution you work at.

2. List the technologies, forms, methods, techniques and teaching tools that you use in your teaching activities.

3. Do you use any modern methods, forms, technologies of development of language and communicative competence of specialists? What? 
4. What information sources do you use to improve your skills of using innovative methods, forms, educational technologies?

5. What scientific schools are developing in the educational institution you work at? Do you adapt their professional best practices?

6. What forms, methods, technologies do you use to foster your own andragogical competence, given the specifics of teaching?

7. Do you use the methods and forms of museum pedagogy in your pedagogical activities? What pedagogical activities do you apply them to? What disciplines do you use them in?

8. What kind of assistance would be the most useful to you when organizing the process of in-service education of the teachers?

9. What methods, forms, technologies of adult education do you consider to be the most effective in your own professional development: occupational training, simulation exercises, pedagogical workshops, master classes, case studies, briefings, disputes, scientific workshops, round table conferences? Underline what you have chosen. Your suggestions.

10. Make your suggestions, recommendations, and ask questions to scientists and colleagues who are studying the problem of developing and implementing adult education technologies in formal and non-formal education settings? 